\title{
Proposal of a Model for Building Human Capital in an Organizational Environment
}

\author{
Victor Mignenan \\ University of Quebec \\ University of Chad at Moundou
}

Studies on human capital, conducted to date, have clearly revealed its importance for organizations. However, its building in the workplace remains less explored. Even research on its model is scarce. In order to understand the variables to be prioritized, a survey of Chadian HRM practitioners and theoreticians was conducted. We deployed the mixed methodology. Data were generated through 11 semistructured interviews and 178 survey. The step-by-step deconstruction approach of the human capital building process, from intake to tenure, was used. The results showed that in the onboarding stage of human capital in an organizational setting, coaching practices foster skills to perform tasks in a structured manner. Then, at the integration stage, coaching practices and investments in training are two levers of efficiency. Finally, in the tenure phase, we found that investments in training do make a difference, but it is mostly experiential opportunities and the agile environment that help build better talent in the workplace. This article is in line with the theory of resources and the theory of skills.

Keywords: agility, human capital, experience, training, investment

\section{INTRODUCTION}

All social organizations have human capital (HC) (Vinokur, 2014). Although it varies from individual to individual, this set of skills, knowledge, qualifications, or other capabilities that an individual possesses for productive purposes is essential for the survival of an organization. Many jobs usually measure HC by the number of years of education (Becker, 1962; Oxley, Lee and Gibson, 2008; Robinson, Hooker and Mercer, 2008). While some believe that education implies a formal education and therefore this measure ignores other HC acquisitions available to the individual (Bouteiller, Cossette, Fournier et Sabourin, 2013; OCDE, 1998). The proponents of this view point to underdeveloped countries where access to education is very heterogeneous in terms of quality, quantity and form. This is why some authors believe that the measurement of $\mathrm{HC}$, exclusively by educational attainment, would be biased, in part, because of this heterogeneity. However, most authors believe that $\mathrm{HC}$ remains an important and essential lever for development and growth (Antonelli, Antonietti et Guidetti, 2010; Bosma, Praag, Thurik et Wit, 2002). It is a privileged vector to enable the organization to achieve its mission (Oxley and al., 2008; Robinson et al., 2008). It also allows the company to position itself strategically in a competitive environment. This is why it is considered the most important dimension of intellectual capital.

Despite its importance, the $\mathrm{HC}$ is not always adequately represented and optimized because of its multidimensional character. This research will allow us to grasp the complexity of the problem of building 
$\mathrm{HC}$, to account for it, and thus to improve its valorization. The theories surrounding HC lead us to believe that this capital is valuable for the company, but still poorly corroborated, according to Mark Blaug's Popperian expression (1976). Consequently, it remains a grey area as to the modalities of its construction and the strategy that can promote its optimization. Thus, in this article, we acknowledge the success of HC rather than emphasizing its shortcomings and assumptions. We intend to contribute to its renewal and revalorization. In this perspective, we will ignore the positivist Walrasian or Marxist perspectives. We will adopt a modified point of view whose premises are to be found in the economics of innovation. To successfully conduct this research, the guiding thread is the following question: what variables are considered relevant to develop the best model of $\mathrm{HC}$ in an organization? This research aims to identify the variables that enter into the process of building $\mathrm{HC}$ in the workplace, respectful of the current challenge of change. From a scientific point of view, $\mathrm{HC}$ is a concept with a high potential for scientific production that has not yet been fully explored and optimized. Through this research, it will be possible to draw a clear and acceptable framework for the endogenous valorization of $\mathrm{HC}$.

\section{THEORETICAL BACKGROUND}

The importance of $\mathrm{HC}$ has encouraged the construction of its modern theory since the 1960s (Becker, 1962, 2009). The relatively exhaustive literature has been extended to make its contents explicit and highlight its scope. Individual and organizational actors have contributed to the related literature (Becker, 1962; OECD, 1998; Vinokur, 2014). To highlight its importance, the OECD (OECD, 1998) revealed that human capital investment would be the trajectory to achieve organizational growth. Other works inclined to the growth of $\mathrm{HC}$ postulate that training and experience opportunities are levers to build a competent $\mathrm{HC}$ (Bouteiller et al., 2013; Keeley, 2004; Yaroson, Esew, \& Abdul-Qadir, 2017).

Figure 1 shows the three factors that are regularly put forward to explain competent human capital in an organizational setting. Figure 1 shows that the valuation of human capital rests on three pillars: training, management and experience. It is generally accepted that this concept is ill-founded, but it is remarkably fruitful and provides a better basis for several theoretical investigations in the fields of distribution (earnings functions) and growth (development economics and endogenous growth). However, while the notion of $\mathrm{HC}$ is widely understood, it is more difficult to find a definition that is unanimously recognized and accepted by researchers. In the following sequence, we will try to suggest a definition for our work.

FIGURE 1

\section{TRIANGLE OF HUMAN CAPITAL CONSTRUCTION IN ORGANIZATIONAL SETTINGS}

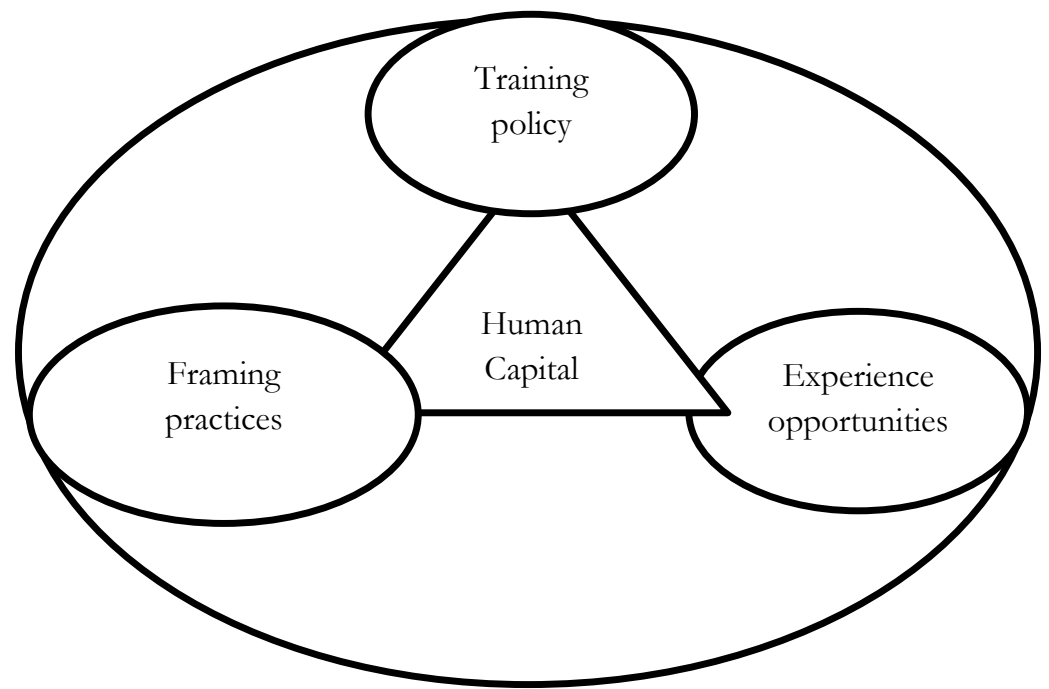

Source: Data compiled from the literature (author, 2020) 


\section{Human Capital: Defining Concept}

The formulation of the concept "human capital" is not accidental. Indeed, according to theorists and practitioners, human capital is considered at the same level of importance as financial capital. Theorists and practitioners see it as a source of wealth and value (Bouteiller et al., 2013; Keeley, 2004; OECD, 1998; Yaroson et al., 2017). According to these authors, human capital participates effectively in improving productivity, but also plays a key role in innovation. While a few authors believe that $\mathrm{HC}$ is similar to emotional capital (Robinson et al., 2008; Vinokur, 2014) and relational capital. The first dimension is characterized by the emotional competencies that the person possesses; these are the abilities that are favorable to personal, professional and organizational development. The second dimension concerns the more or less institutionalized relational networks (Bourdieu, 1980). According to several authors, an organization's HC can grow, shrink, or even become useless if relevant initiatives are not taken to improve its components. Despite its usefulness in an organizational environment, there is little consensus on the definitional concept of human capital. According to Joseph Stiglitz (2014), human capital is the accumulated knowledge, skills and experience that make employees more productive. In the same vein, several authors (Ugalde-BindaI, Balbastre-Benavent, Canet-Giner) et Escribá-Carda, 2013) state that HC is a heritage of knowledge to be developed and not an instrument of production. It certifies the ability of an individual or a population to perform tasks and is the result of an investment in education and continuing education. Rodriguez and Loomis (J. P. Rodriguez) et S. R. Loomis, 2007) define human capital as a set of knowledge, skills, competencies, and attributes that contribute to the construction of personal, economic and social well-being. According to Becker (1962), HC is an individual's resource that determines his level of productivity. Table 1 provides a definitional synthesis.

TABLE 1

DEFINITIONS OF THE CONCEPT OF "HUMAN CAPITAL

\begin{tabular}{|l|l|l|}
\hline Authors & Definition & $\begin{array}{l}\text { Concept retained } \\
\text { for this work }\end{array}$ \\
\hline $\begin{array}{l}\text { Joseph Stiglitz } \\
(2014),\end{array}$ & $\begin{array}{l}\text { It is the accumulated skills and experience that make } \\
\text { employees productive. }\end{array}$ & $\begin{array}{l}\text { Skills and } \\
\text { experience, more } \\
\text { productive employee. }\end{array}$ \\
\hline $\begin{array}{l}\text { P. J. Rodriguez, } \\
\text { R.S. Loomis } \\
(2007)\end{array}$ & $\begin{array}{l}\text { Knowledge, skills, competencies, and attributes that } \\
\text { facilitate the creation of personal, economic and social } \\
\text { well-being. }\end{array}$ & $\begin{array}{l}\text { Knowledge, skills, } \\
\text { competencies, and } \\
\text { attributes. }\end{array}$ \\
\hline OECD (1998) & $\begin{array}{l}\text { All the knowledge, qualifications, skills, and other qualities } \\
\text { possessed by an individual and relevant to economic } \\
\text { activity. }\end{array}$ & $\begin{array}{l}\text { Knowledge, skills, } \\
\text { competencies. }\end{array}$ \\
\hline $\begin{array}{l}\text { Gary Becker } \\
(1962)\end{array}$ & $\begin{array}{l}\text { An individual's resources that influence the future real } \\
\text { income generated by either education or on-the-job } \\
\text { training. Here, human capital investment is classified by its } \\
\text { general or specific nature. }\end{array}$ & $\begin{array}{l}\text { Resources of an } \\
\text { individual. }\end{array}$ \\
\hline $\begin{array}{l}\text { Theodore } \\
\text { Schultz (1961) }\end{array}$ & $\begin{array}{l}\text { Characteristics of the worker that determine his or her level } \\
\text { of productivity: health, adult continuing education, } \\
\text { education, migration, and on-the-job training (or motor } \\
\text { skills, work methods, intellectual knowledge). }\end{array}$ & $\begin{array}{l}\text { Motor skills, work } \\
\text { methods, intellectual } \\
\text { knowledge. }\end{array}$ \\
\hline
\end{tabular}

Source: Data compiled from the literature (author, 2020)

These definitions are based, for the most part, on Walrasian and Marxist positivist premises. In this paper, human capital (HC) is seen as a conceptual construct and a category of the practice of the individual's relationship with the workplace. In this view, HC is understood as "the set of new knowledge, skills, abilities, etc. that each individual has acquired through training, experience, coaching, and agility during his or her working life cycle, enabling him or her to perform, in a structured way, the tasks in the workplace. 


\section{Theoretical Framework of Human Capital}

Human capital in an organizational environment is diluted in the person who built and acquired it. It is specific to each individual insofar as it is the reflection of a personal history and a singular path related to the professional life cycle. The process of human capital development can come from: (i) formal education; (ii) training in an organizational setting; (iii) experience acquired during working life in the vast array of learning (networks of interests, internship of impregnation, families or communities); but also, from the agile environment.

Becker (2009), who systematized the theory of human capital, was inspired by the founding work of Schultz (1961). The basic premise of this theory is based on the following reasoning: the wealth of Man is based on his potential knowledge, skills, know-how, behavioral intelligence, etc. This is a real capital that can be used to improve the quality of life. This is a real capital that can be developed and enriched in the same way as material capital. The organization that uses the individual as a subject for growth must work to enrich not only the individual's knowledge, but also his or her development from the moment he or she joins the company and throughout his or her time with it. According to Becker, there are two types of investment in human capital: investment made ex ante in the labor market (education) and investment made during one's journey in the workplace (continuous training). Becker notes that the initial training of the individual is not sufficient. Consequently, the individual, with the contribution of his or her organization, must frequently evolve (stages of induction to permanence) his or her knowledge in order to adapt it to the changes in the environment. Moreover, investments in human capital can be general or specific. However, they all aim to provide new knowledge, skills and abilities related to technical or administrative processes that are specific to an organization.

\section{The Contribution of Resource Theory to Human Capital}

The theory of resources, which underlies managerial practices, provides strategic management tools for personnel management. More specifically, it encourages the replacement of human capital at the center of the company's strategy. Similarly, it promotes the legitimacy of a strategic vision of the management of an organization's intangible capital. Resource theory facilitates the understanding of the grey area surrounding the issue of sustainable differentiated performance. In the same perspective, Barney reveals that in order to deploy strategies that promote effectiveness and efficiency, the organization is called upon to maintain its resources, particularly its human capital (Barney, 1991). In order for this resource to be competitive and sustainable, the organization must add value to it to make it agile so that it is the master of strategic innovation. It is for this reason that several schools of thought put forward the agile environment to explain the performance of human capital.

For these authors, since $\mathrm{HC}$ is the most important of all resources, it is the organization's responsibility to contribute to its construction and development. Thus, the manager's responsibility is to deploy better organizational practices (management, leadership, governance) that can foster an agile environment, but also significant investments. It is in this perspective that currents of thought are emerging that contribute to building human capital. These include the knowledge and skills perspectives. These perspectives gave rise to the education-training variable in the theory of human capital conceptualized by Schultz (1961). According to Schultz, in order to make the individual effective for the organization, investments must be made that generate new knowledge and experience.

\section{The Contribution of Competence Theory to Human Capital}

The central idea of the theory of competencies considers the organization as a grouping of human and material resources dedicated to production. It considers human capital as the unique and not easily transferable means of production. According to the perception of the theory of competences (Barney, 1991), the $\mathrm{HC}$ embodies values and heritage to be fructified in order to be the source of a sustainable competitive advantage (Kungwansupaphan et Siengthai, 2012). It is in this perspective that some authors (Chamak and Fromage, 2006; Crook, Combs, Todd, Woehr, and Ketchen, 2011; Nafukho, Hairston, and Brooks, 2004; Vinokur, 2014) have revealed that the knowledge embodied in human capital is the most valuable and most difficult to imitate heritage. Thus, they suggest that companies implement a "competency-based" 
management approach, focused on the individual, and seeking above all to support and prepare employees, who are a growth asset, to face an environment that is constantly accelerating under the effect of information and communication technologies.

\section{Building Human Capital}

Human capital is seen as a singular concept. It is generally believed to be ill-founded, yet it is extremely fruitful for the organization. It also offers many opportunities for research, both theoretical and empirical. However, an interdisciplinary consensus is emerging around the construction of intellectual capital. Thus, the idea of investing in people in an organizational environment has become necessary to respond to technological and economic changes. This implies a shift from a capitalist business model to a managerial business posture. It is in this perspective that Adam Smith, quoted by the OECD, noted that what fuels economic activity is the useful talents acquired, which must be maintained through coaching (Bosma et al., 2002; OECD, 1998).

Several authors find a strong causal relationship between improvements in the firm's managerial practices, investments in people, coaching and the agile environment, and the acquisition of effective human capital (Kungwansupaphan et Siengthai, 2012; Yaroson et al., 2017). For some works, the company's social policy should give low-skilled employees the opportunity to benefit from continuous training and the agile environment to deploy their talent (Nafukho et al., 2004; J. Rodriguez et S. Loomis, 2007). However, several authors find the problem tricky, as it relies, in part, on the structure of the firm (OECD, 2013; Ugalde-BindaI et al., 2013; Unger, Rauch, Frese and Rosenbusch, 2011). Others believe that the minimum is to create, within the company, from the integration phase, an agile environment to new recruits (Ahmad et Mushraf, 2011; AL-Duajaili, 2012). Similarly, some authors find it relevant to initiate qualifying training for all new employees to enable them to perform tasks in the most structured way (Lev et Han, 2015).

By way of summary, Figure 2 shows the relationship between the main variables that play a decisive role in the construction of competitive $\mathrm{HC}$.

FIGURE 2

\section{COMPONENTS OF THE THEORETICAL FRAMEWORK}

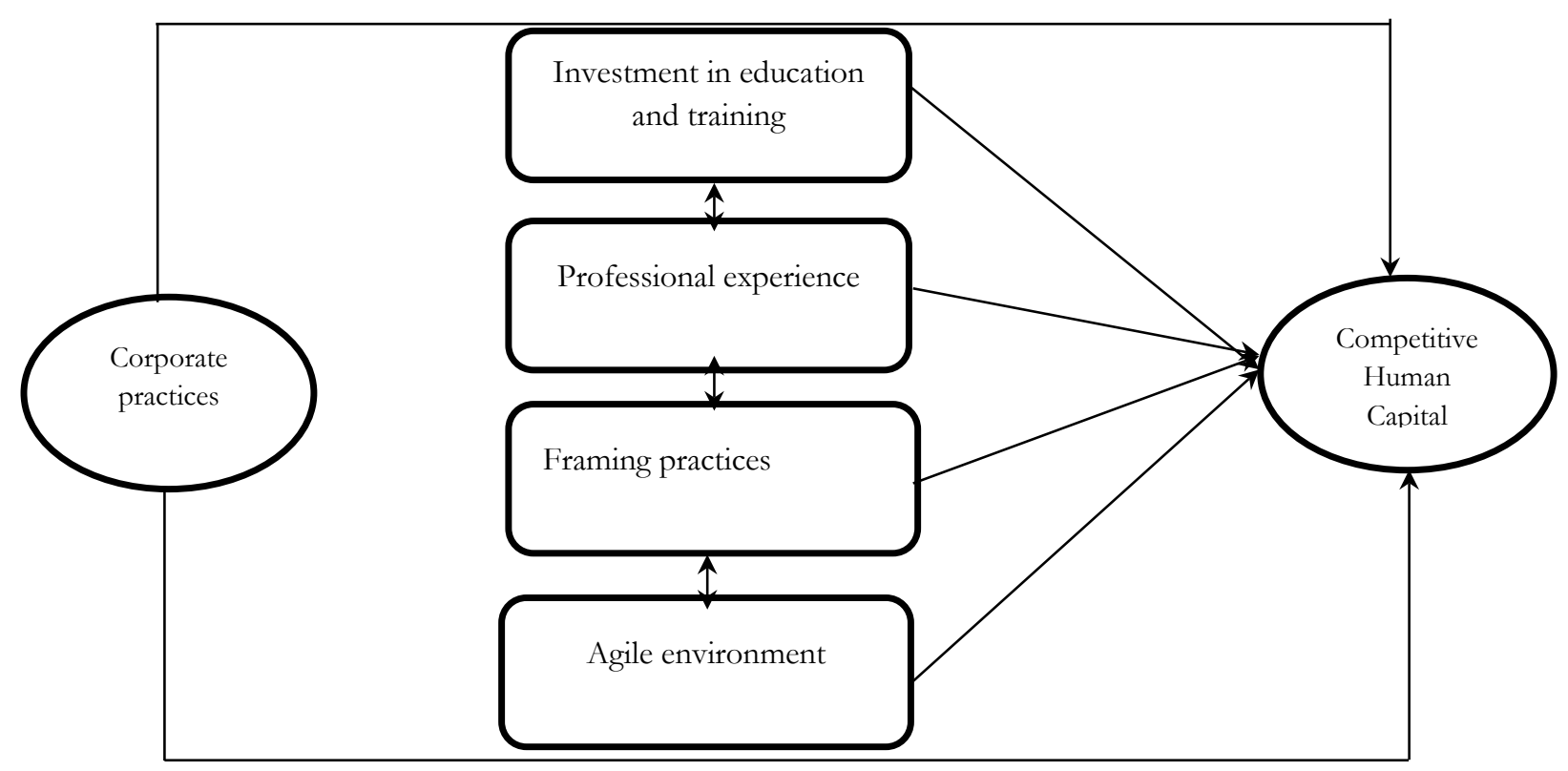

Source: Data compiled from the literature (author, 2020)

This construction of competitive human capital (CHC) (Figure 2) makes explicit the interactions between business practices and HC. These relationships, which drive the model, require refinements to 
estimate the parameters. These relationships focus on the practices of the firm in relation to the different facets of $\mathrm{CH}$ the managerial practices of the organization. These practices will promote investment, leadership, experience, and agility as factors contributing to the construction of HC. The articulation of these variables is based on the Structure-Style of management-HC paradigm.

\section{Conceptual Framework}

In light of Figure 2, the building of a person's human capital in the workplace begins on the first day (onboarding stage) of employment, through coaching/support, and continues through to the end of the work life cycle (tenure stage). Thus, resource and competency theory posit that investments in training, coaching, experience, and agility, fostered by managerial business style, contribute positively to the construction of competitive human capital (Becker, 2009; OECD, 2013; Vinokur, 2014; Yaroson et al., 2017). This construction is enriched and developed throughout the working life cycle.

Therefore, our conceptual model of CHC construction which is represented by Figure 3, is based on the Structure-Practice-Outcome scheme.

FIGURE 3

CONCEPTUAL MODEL

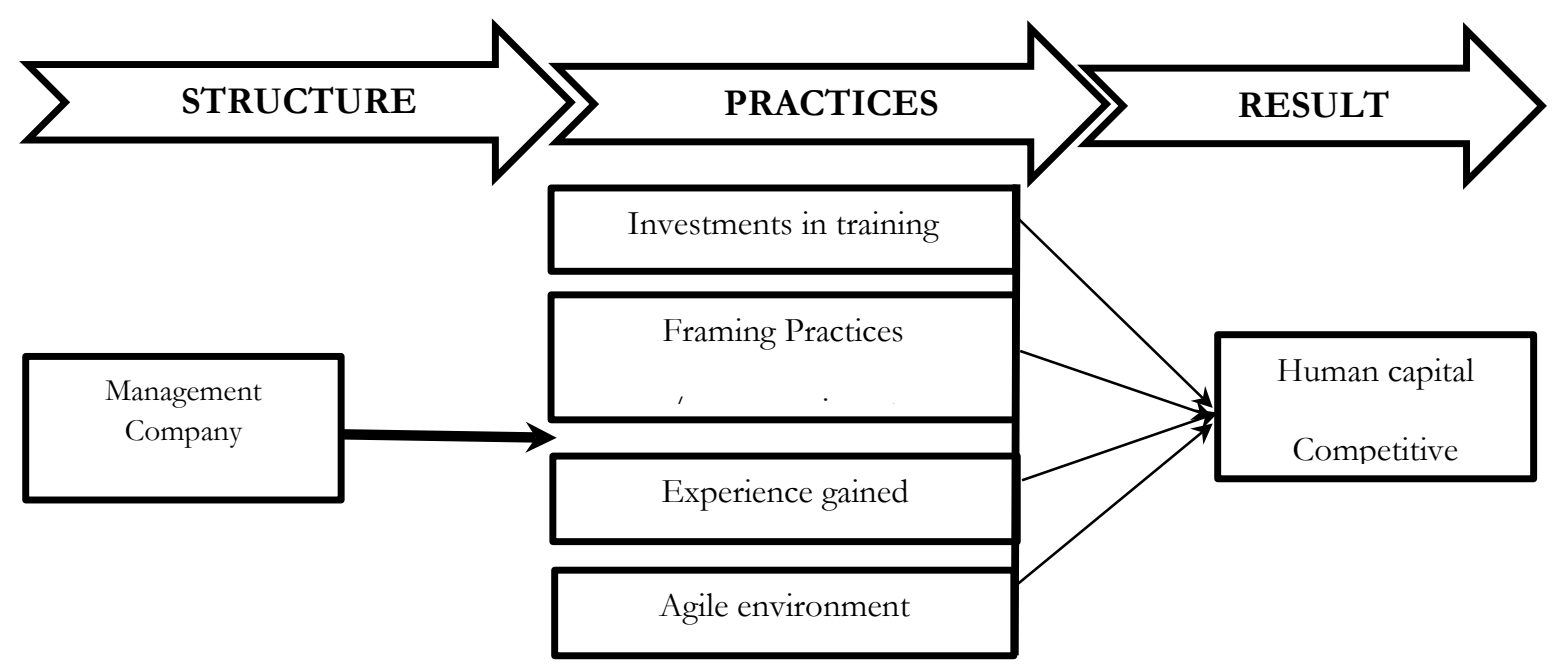

Source: Data compiled from the literature (author, 2020)

\section{FORMULATION OF RESEARCH HYPOTHESES}

Our reflection is built around the assumption that, thanks to favorable managerial styles, the companies studied deploy relevant actions to enrich and develop the new knowledge and skills of the human capital they have acquired. We retain the general hypothesis that considers human capital as a multidimensional construct: it is constructed simultaneously by training, coaching, experience, the agile environment and, indirectly, by the organization's structures. Four hypotheses adjacent to the general hypothesis are suggested. The following lines report on the four hypotheses.

\section{Investment in Training and Competitive Human Capital}

Investment in training is the inclusion in the organization's budget of a line item dedicated to activities that can enrich and develop the knowledge of staff. Economists and HRM specialists believe that investment in continuous training of employees works in favor of building the best talent (Becker, 1962; Fraisse-D'Olimpio, 2009; Kalkan, Bozkurtb and Arman, 2014; Lleras, 2004; OECD, 1998; Schultz, 1961; Stiglitz et al., 2014). Becker's contributions have converged in the same direction by emphasizing the importance of training by doing. This suggests that investments in human capital in organizational settings 
are long-term and that the role played by the firm is critical. In light of this finding, the first research hypothesis below is formulated:

Hypothesis 1. Investments in training increase the competence of human capital.

\section{Coaching Practice and Competitive Human Capital (CHC)}

Staff supervision refers to the guidance and support mechanisms developed for the benefit of new recruits. It consists of facilitating insertion, integration, but above all the execution of tasks in a structured manner. Accompaniment is considered to be one of the effective activities for building $\mathrm{CHC}$ in the professional life cycle. Several authors have noted a positive influence of the coaching and support practices offered during the professional life cycle (induction-integration-permanence stages) on the increase in staff ability (Crook et al., 2011; Keeley, 2004; Nafukho et al., 2004). This leads us to formulate the second hypothesis as follows:

\section{Hypothesis 2. Staff management practices improve human capital competence.}

\section{Opportunities for Experience and Competitive Human Capital}

Experience is understood in terms of a variety of skills built through action and contact with the field, job, function or position. HR managers agree that when opportunities to increase and diversify experiences are created for the benefit of staff, it promotes the emergence of skillful talents within workers, starting from the induction stage to tenure (Becker, 2009; OECD, 2013; Yaroson et al., 2017). This relationship leads us to suggest the following third hypothesis:

Hypothesis 3. The more experience opportunities the organization creates, the more competent its human capital would be.

\section{Agile Environment and Competitive Human Capital}

Agility is understood as a mode of personnel management that gives importance to collaborative work and collective intelligence as a factor of individual productivity. The philosophy of agility is based on continuous improvement, constant innovation, but above all, the questioning of methods in order to truly meet the expectations of the organization's stakeholders, but also of the ecosystem in perpetual change. The renewed approaches in project management consider the agile environment as a factor positively and statistically significant associated with CHC. As such, we suggest the following fourth hypothesis:

\section{Hypothesis 4. The agile environment contributes to building competitive human capital.}

In order to ensure that the said relationships carried by these variables, at the theoretical and managerial levels, echo the concerns of theorists and practitioners, an appropriate methodology is essential. This is the purpose of the following sequence.

\section{METHODOLOGICAL PATH}

\section{Approach}

Proponents of human capital theory agree on its multidimensional character, but also on its interdisciplinarity. Thus, proposing and testing a model for the construction of such a construct calls for the mobilization of a hybrid methodological framework. Consequently, the mixed approach (Creswell, 2013), which simultaneously combines qualitative and quantitative methods, has been recommended.

Indeed, in a first step, the documentary analysis was deployed, as it is the method par excellence, not only to apprehend the different facets of human capital in its construction process, but also to identify the relevant variables that participate in it. We thus explored articles and reports. These various consultations 
have made it possible to: (i) draw a portrait of human capital in an organizational environment and its construction process and (ii) apprehend the different theoretical currents around competitive human capital.

Second, we advocated the semi-structured interview, which is widely recommended and used in the field of management science (Evrard and al., 2009). In this type of interview, respondents have a range of freedom to provide detailed and more complete information. Thus, 11 semi-structured, individual, face-toface and telephone interviews were conducted with each personnel manager who voluntarily agreed to be interviewed. These 11 respondents were from 6 companies in the manufacturing sector. They were selected because of their commitment to the implementation of corporate social responsibility policies in Chad. This commitment was fostered by the recommendations of the National Symposium on Corporate Social Responsibility and Sustainable Development.

The implementation of the interview is preceded by the construction of a semi-directive interview guide. This guide, which serves as a guideline, was built on the basis of information generated from the literature. It is structured according to the following four themes.

$\checkmark$ Theme 1: Investments in continuing education.

$\checkmark$ Theme 2: Staff management practices.

$\checkmark$ Theme 3: Staff Experience Opportunities.

$\checkmark$ Theme 4: Agile environment.

It should also be noted that our respondents were graciously familiar with the four interview themes. This advantage helped us reach the saturation point after conducting the 11 interviews, mostly by convenience, in the city of Moundou (Chad) during the months of November to December 2019 with an average duration of 25 minutes per head of staff. Table 2 reports the characteristics of the interview respondents.

TABLE 2 CHARACTERISTICS OF RESPONDENTS TO THE INTERVIEWS

\begin{tabular}{|c|c|c|c|c|c|c|c|}
\hline \multicolumn{3}{|c|}{ Company information } & \multicolumn{5}{|c|}{ Information about the interviewees } \\
\hline Status & Sector & $\begin{array}{l}\text { Average } \\
\text { size }\end{array}$ & $\begin{array}{l}\text { Date/period } \\
\text { interview }\end{array}$ & $\begin{array}{l}\text { Average } \\
\text { duration }\end{array}$ & $\begin{array}{l}\text { Seniority } \\
\text { in the } \\
\text { position }\end{array}$ & Category & $\begin{array}{l}\text { Number of } \\
\text { interviewees }\end{array}$ \\
\hline $\begin{array}{l}\text { Limited } \\
\text { liability } \\
\text { company }\end{array}$ & $\begin{array}{l}\text { Dairy } \\
\text { products }\end{array}$ & 51 & \multirow{4}{*}{$\begin{array}{l}\text { November } \\
\text { to } \\
\text { December } \\
2019\end{array}$} & $\begin{array}{l}26 \\
\text { minutes }\end{array}$ & $7-15$ & $\begin{array}{l}\text { Chief of } \\
\text { Staff }\end{array}$ & 6 \\
\hline $\begin{array}{l}\text { Limited } \\
\text { company }\end{array}$ & $\begin{array}{l}\text { Oil, } \\
\text { beverages }\end{array}$ & 212 & & $\begin{array}{l}28 \\
\text { minutes }\end{array}$ & $5-11$ & $\begin{array}{l}\text { Director } \\
\text { of Human } \\
\text { Resources }\end{array}$ & 3 \\
\hline $\begin{array}{l}\text { Economic } \\
\text { Interest } \\
\text { Grouping }\end{array}$ & $\begin{array}{l}\text { Pasta and } \\
\text { flour }\end{array}$ & 37 & & $\begin{array}{l}22 \\
\text { minutes }\end{array}$ & $4-9$ & Manager & 2 \\
\hline & & & & & & & 11 \\
\hline
\end{tabular}

Source: Data compiled from the literature (author, 2020)

In terms of analysis technique, we borrowed lexical and thematic content analysis. Table 3 shows how the two qualitative analysis techniques were deployed. Next, an analysis grid was developed according to the four themes from the interview guide initially developed for the purpose. This grid was filled in according to the code of the interviewees and the units of analysis, which were subjected to vertical and horizontal analyses, along with a summary table. 
TABLE 3

TECHNIQUES OF ANALYSIS

\begin{tabular}{|l|l|l|}
\hline $\begin{array}{l}\text { Nature of qualitative } \\
\text { analysis }\end{array}$ & Components & Relevance Indicators \\
\hline Lexical & $\begin{array}{l}\text { Words used, phrases } \\
\text { used }\end{array}$ & $\begin{array}{l}\text { Type and quality of vocabulary used. } \\
\text { E.g.: frequency of occurrence of words, average } \\
\text { number of words per sentence, etc. }\end{array}$ \\
\hline Theme & $\begin{array}{l}\text { Sentences, } \\
\text { paragraphs, themes } \\
\text { E.g.: frequency of appearance of themes, } \\
\text { frequency of association }\end{array}$ \\
\hline
\end{tabular}

Source : Adapted from Evrard et al. 2005

The lexical and thematic content analysis brought out new facets of the construction of competitive human capital in the workplace. Also, the results confirmed the dimensions of continuous training and the agile environment in the process of building competitive human capital in the workplace. Similarly, the lexical and content analysis helped to identify the words and themes frequently evoked by managers to shed light on the construction of competitive human capital.

Thirdly, the explanatory phase is based on the hypothetical-deductive approach. We have previously formulated four research proposals based on the literature review. The choice of the hypothetico-deductive reasoning is motivated by the vast amount of knowledge on human capital, which is remarkably enriched by the semi-directive interviews. Data generation was accomplished through face-to-face and online surveys (on a five-point Likert scale) from December 2019 to March 2020. The formulation of the items preceded the development of the questionnaire, which is composed mainly of the variables that emerge and the full accounts commented by some specialists and professionals (HRM research firm) complemented by the exploitation of documentation from the literature. The questionnaire developed was pre-tested with 14 personnel managers and directors of human resources consulting firms. These respondents were selected on the basis of their expertise in human capital management.

To determine the sample size, we followed the path recommended by Igalens and Roussel (1998), who suggest that the sample size is proportional to the number of items, i.e., 5 to 10 times more respondents than there are items describing the constructs under study. In total, 20 items were formulated to measure the 5 constructs. Thus, we have $5 \times 20$ and $10 \times 20$, i.e., between 100 and 200 . We opted for the high bound, i.e. $n=200$ respondents, considered as reporting units. The 200 respondents are from 10 firms (with at least 20 employees each - according to the National Agency for Investment and Exports (ANIE) in the manufacturing sector, randomly selected from the ANIE database (Anie-Tchad, 2017). The questionnaire was sent to the head of the company. Those who completed it were personnel managers or heads of administrative units in the company. After two reminders, a total of 178 questionnaires were received; $71.2 \%$ of them were used in the analysis. Table 4 presents the characteristics of the field companies in this research.

TABLE 4

CHARACTERISTICS OF THE SAMPLE

\begin{tabular}{|c|c|c|c|c|c|c|}
\hline \multirow[t]{2}{*}{$\mathbf{N}^{\circ}$} & \multirow[t]{2}{*}{ Status } & \multirow[t]{2}{*}{ Sector } & \multirow[t]{2}{*}{ Size (N) } & \multicolumn{3}{|c|}{ Sample } \\
\hline & & & & Size & $\begin{array}{l}\text { Hierarchical } \\
\text { level }\end{array}$ & $\begin{array}{l}\text { Experience } \\
\text { (in years) }\end{array}$ \\
\hline 1 & \multirow{4}{*}{ SARL } & Dairy products & 26 & 10 & \multirow{4}{*}{$\begin{array}{l}\text { Technicians } \\
\text { and middle } \\
\text { management }\end{array}$} & \multirow{4}{*}{1 to 10} \\
\hline 2 & & Fruit jams & 25 & 10 & & \\
\hline 3 & & Pasta & 22 & 10 & & \\
\hline 4 & & Bakery & 24 & 10 & & \\
\hline
\end{tabular}




\begin{tabular}{|c|c|c|c|c|c|c|}
\hline 5 & \multirow[t]{4}{*}{ SA } & Vegetable oil & 75 & 45 & \multirow{4}{*}{$\begin{array}{l}\text { Labourers, } \\
\text { Technicians, } \\
\text { middle } \\
\text { management }\end{array}$} & \multirow[t]{4}{*}{1 to 15} \\
\hline 6 & & $\begin{array}{l}\text { Alcoholic and } \\
\text { carbonated beverages }\end{array}$ & 62 & 35 & & \\
\hline 7 & & Mineral water & 53 & 30 & & \\
\hline 8 & & Sugar bowl & 63 & 30 & & \\
\hline 9 & \multirow[t]{2}{*}{ GIE } & Shea butter & 27 & 10 & \multirow{3}{*}{$\begin{array}{l}\text { Technicians } \\
\text { and middle } \\
\text { management }\end{array}$} & \multirow[t]{3}{*}{1 to 9} \\
\hline 10 & & Peanut butter & 29 & 10 & & \\
\hline Total & & & 406 & 200 & & \\
\hline
\end{tabular}

Source: Data compiled from the literature (author, 2020)

\section{Variables and Measurements}

The measures adopted in our research are based on previous qualitative and quantitative studies (Becker, 2009; Bouteiller et al., 2013; Crook et al. , 2011; Yaroson et al. , 2017). We have adapted them to the context of Chadian firms.

\section{Independent Variables}

We borrowed indicators from the full account and those commonly used in the assessment and measurement of the variables training, coaching, experience, agile environment (Becker, 1962; Keeley, 2004; Lleras, 2004; OECD, 1998; Oxley et al., 2008; Poulain, 2001; Robinson et al., 2008; Schultz, 1961):

$\checkmark$ For training, we focused on: (i) frequency of training; (ii) training topics; (iii) results, effects, and impact on the $\mathrm{HC}$.

$\checkmark$ With regard to accompaniment/supervision, we have retained the following three indicators: (i) technical support; (ii) administrative support; (iii) pedagogical support.

$\checkmark$ For the experience, we opted for: (i) the richness of networking; (ii) trips/work missions; (iii) company visits.

$\checkmark$ For the agile environment, the focus is on: (i) the level of staff autonomy; (ii) tolerance for risk of failure; (iii) synchronized collaboration; and (iv) the level of customer interaction.

The variables explored used five-point Likert scales (ranging from [1] strongly disagree to [5] strongly agree). The alpha reliability (Cronbach's coefficient) of the scales ranged from .94 to .96 (Becker, 2009; Bessieux-Ollier \& Walliser, 2010; Bouteiller et al., 2013; Keeley, 2004; Poulain, 2001; Robinson et al., 2008; J. Rodriguez \& S. Loomis, 2007).

\section{Dependent Variable (Competitive Human Capital)}

The indicators selected, given their regularity in the literature, are: (i) new knowledge gained; (ii) intensity of motivation; (iii) level of creative spirit; (iv) participation in staff goals; (v) improved social balance; and (vi) level of staff ability/skill (Nafukho et al., 2004; OECD, 1998; Oxley et al., 2008; Robinson et al., 2008; Schultz, 1961; Vinokur, 2014; Yaroson et al., 2017). Responses were obtained using a Likert scale (ranging from [1] strongly disagree to [5] strongly agree). The alpha reliability of the scale is 0.77 .

\section{RESULTS AND DISCUSSION}

\section{Results}

Qualitatively, we highlighted the full reports initially generated. Table 5 presents a portrait of these reports. 


\section{TABLE 5 \\ FULL REPORTS}

\begin{tabular}{|c|c|}
\hline $\begin{array}{l}\text { Variables } \\
\text { tested }\end{array}$ & Verbatims \\
\hline $\begin{array}{l}\text { Investment in } \\
\text { training }\end{array}$ & $\begin{array}{l}\text { - We train all new personnel recruited; } \\
\text { - } \quad \text { We offer in-house training to all new employees; } \\
\text { - Each year, we pay } 1.8 \% \text { of our payroll for the continuing education of our staff; } \\
\text { - } \quad \text { We have elaborated a manual in which the policy and the plan of continuous } \\
\text { training of the personnel are defined; } \\
\text { - We have signed an agreement with social auditing firms that provide two missions } \\
\text { per year; } \\
\text { - }\end{array}$ \\
\hline $\begin{array}{l}\text { Framing } \\
\text { practices }\end{array}$ & $\begin{array}{l}\text { - We have put in place an insertion coaching system for all new recruits; } \\
\text { - } \quad \text { All former employees play the role of support and mentoring; } \\
\text { - In our company, each department head is responsible for the management of the } \\
\text { company; } \\
\text { - In our slogan, the department manager is a coach; } \\
\text { - Within our company, there is the support service for new recruits; } \\
\text { Here at our company, we talk about coaching for new recruits. }\end{array}$ \\
\hline $\begin{array}{l}\text { Experience } \\
\text { opportunities }\end{array}$ & $\begin{array}{l}\text { - Depending on the employee's level of responsibility and position, professional } \\
\text { missions and trips are regularly organized according to the company's needs. } \\
\text { Training courses are also organized for technical staff; } \\
\text { - } \quad \text { Experience opportunities are created a lot internally; } \\
\text { - } \quad \text { The tour of the various departments is an opportunity for experience; } \\
\text { - We have initiated impregnation visits for some staff; } \\
\text { - } \quad \text { We have organized forums in our network to exchange experiences. }\end{array}$ \\
\hline $\begin{array}{l}\text { Agile } \\
\text { environment }\end{array}$ & $\begin{array}{l}\text { - We promote teamwork; } \\
\text { - Teamwork is part of our cultural values, as it is essential for collective learning, } \\
\text { creativity, innovation and problem solving; } \\
\text { - Our staff, including sales agents, prospects, and the sales force, work as a team to } \\
\text { create value and benefits; } \\
\text { - Sometimes, in teams, some people do little work; } \\
\text { - } \quad \text { The staff regularly asks us for autonomy for developmental purposes; } \\
\text { - } \quad \text { For us, cooperative work is a kind of collective organization of work; } \\
\text { - I think that collaborative work is a collective work situation; } \\
\text { - } \quad \text { We advocate organizational flexibility; } \\
\text { - It is our policy that each department head must be risk tolerant; } \\
\text { - } \quad \text { We promote organizational autonomy in all departments. }\end{array}$ \\
\hline
\end{tabular}

The analysis of the verbatims in Table 5 identified new concepts that serve as emergent variables. Table 6 reports the result. 


\section{TABLE 6 \\ EXAMPLES OF FULL REPORTS}

\begin{tabular}{l|l|l}
\hline $\begin{array}{l}\text { Variables } \\
\text { tested }\end{array}$ & Verbatims & $\begin{array}{l}\text { Emerging } \\
\text { variables }\end{array}$ \\
\hline $\begin{array}{l}\text { Investments } \\
\text { in training }\end{array}$ & $\begin{array}{l}\text { Existence of a training policy by administrative unit; 1.8\% of the } \\
\text { wage bill allocated to staff training; an average of two to three staff } \\
\text { training sessions per year; financial partner for training is FONAP } \\
\text { (Fonds national d'appui à la formation professionnelle); existence } \\
\text { of institutions (universities, consultancies, etc.) that offer training } \\
\text { services; but sometimes there is disappointment }\end{array}$ & $\begin{array}{l}\text { Capacity } \\
\text { building, } \\
\text { knowledge } \\
\text { updating. }\end{array}$ \\
\hline $\begin{array}{l}\text { Framing } \\
\text { practices }\end{array}$ & $\begin{array}{l}\text { The personnel department, in collaboration with the various } \\
\text { administrative units, sets up induction and coaching/mentoring } \\
\text { workshops for all new recruits during the first three to four weeks of } \\
\text { service, depending on the new recruit's previous duties and } \\
\text { experience. }\end{array}$ & $\begin{array}{l}\text { Supporting new } \\
\text { recruits, } \\
\text { coaching new } \\
\text { recruits. }\end{array}$ \\
\hline $\begin{array}{l}\text { Experience } \\
\text { opportunities }\end{array}$ & $\begin{array}{l}\text { Depending on the employee's level of responsibility, position and } \\
\text { function, professional missions and trips are regularly organized } \\
\text { according to the company's needs. Training courses are also } \\
\text { organized for technical personnel }\end{array}$ & $\begin{array}{l}\text { Impregnation } \\
\text { visits; meetings } \\
\text { to exchange } \\
\text { experiences. }\end{array}$ \\
\hline $\begin{array}{l}\text { Agile } \\
\text { environment }\end{array}$ & $\begin{array}{l}\text { Teamwork is part of our cultural values, as it is essential for } \\
\text { collective learning, creativity, innovation and problem solving. } \\
\text { Sales agents, prospects, and the sales force work as a team to create } \\
\text { value and benefits. Sometimes, in teams, some people do little work. }\end{array}$ & $\begin{array}{l}\text { Organizational } \\
\text { flexibility; risk } \\
\text { tolerance, and } \\
\text { organizational } \\
\text { autonomy. }\end{array}$ \\
\hline
\end{tabular}

In terms of correlation, we have put forward the mean and standard deviation (SD) parameters. Table 7 reports the results. Generally speaking, the human capital (HC) stakeholders of the companies studied perceive training, coaching, experience and agility as factors in building competitive human capital, from the onboarding stage to integration. In fact, they report that their organization invests in employee training with an average of 3.9 out of $5(S D=1.63)$. They declare that they initiate coaching practices from the onboarding stage, with an average of 3.5 out of $5(\mathrm{~S} . T .=1.45)$. Next, they mention that their organization creates opportunities for experience, during the tenure stage, with an average of $3.6(E c . T .=1.53)$. Finally, they emphasize that their organization creates an agile environment with an average of $4.8(E c . T .=1.65)$. In short, the respondents consider their organizations to be more inclined to value and enrich HC. These results are certainly all positive, although interviews reveal some divergent views, including some company leaders who are not very supportive of continuing education. The results also reveal that respondents share the efforts made by their organizations with respect to investments in continuing education. Indeed, they emphasize initiatives in the areas of agility, training, etc. as variables to be promoted in the process of building competitive human capital. Finally, Table 7 also presents the strong correlational results between the variables. Specifically, agile environment has the strongest $(r=0.96 ; p<.01)$ and statistically positive correlation with CHC. Coaching/support is the second strongly correlated variable $(r=0.91, \mathrm{p}<.01)$ statistically positive with CHC. Training comes in third with a positive and statistically significant correlation $(r=.89, \mathrm{p}<.01)$. Finally, experience is positively associated with $\mathrm{CHC}(r=0.83, \mathrm{p}<.01)$. These results converge with the full accounts from the semi-structured interviews in Table 7, which results are consistent with the research hypotheses. 
TABLE 7

MEANS, STANDARD DEVIATIONS AND CORRELATIONS BETWEEN VARIABLES

\begin{tabular}{l|l|l|l|l|l|l}
\hline Variables & $\begin{array}{l}\text { Average } \\
\text { (S.T) }\end{array}$ & $\begin{array}{l}\text { Competitive } \\
\text { HC }\end{array}$ & Training & Framing & Experience & Agility \\
\hline $\begin{array}{l}\text { Competitive } \\
\text { HC }\end{array}$ & $4,9(1,87)$ & 1 & & & & \\
\hline Training & $3,9(1,63)$ & $0,89^{* *}$ & 1 & & & \\
\hline Framing & $3,5(1,45)$ & $0,91^{* *}$ & $0,74^{* *}$ & 1 & & \\
\hline Experience & $3,6(1,53)$ & $0,83^{* *}$ & $0,67^{* *}$ & $0,88^{* *}$ & 1 & \\
\hline Agility & $4,8(1,65)$ & $0,96^{* *}$ & $0,81^{* *}$ & $0,56^{* *}$ & $0,78^{* *}$ & 1 \\
\hline
\end{tabular}

**p $<, 01$

In conclusion, if every company invests effectively in its staff during every hour of its operating cycle, from intake (hiring to tenure), it would have a competitive $\mathrm{HC}$ to achieve growth.

To test the four hypotheses, we used multiple regression with stepwise variable entry. This method of selecting the variables to be included allows us to check the variation of the coefficient of determination ${ }^{\text {R2 }}$ of each explanatory variable added to the model equation (Alain, 2004). We analyzed the data using SPSS 23.0 software. Table 8 reports the results.

Hypothesis 1. Investments in Training Increase the Competence of Human Capital.

Qualitatively, HR managers and firm leaders are unanimous on the importance of investing in training to build CHC (competitive human capital) in the workplace:

[...] Here, staff training, from the moment they are welcomed and integrated, is a right recognized by the collective agreement. We offer in-house training to all new employees, regardless of their position. Then, in our budget, there is a line dedicated to training; each year, we pay the $1.8 \%$ of the payroll for the continuous training of our staff. This ensures that our employees are always able to perform their tasks in a structured manner and has enabled us to achieve our vision as a leader. ...] we have developed a manual in which the policy and plan for continuous training of staff are defined, in collaboration with the union and with the support of our technical partners (two HR firms, two universities). We have also signed an agreement with a social auditing firm that carries out two missions per year. And our staff is always equipped with new knowledge in occupational safety, new information technology, health insurance and first aid, etc.

These opinions attest to the effectiveness of building CHC through investment in training. However, some managers have reservations about the purpose of training, which is still not well understood by some employees:

[...] two years ago, the realization of the training of our personnel generated enormous conflicts that required the intervention of the work delegate. Indeed, all those who benefited from the training demanded either promotion or a salary increase. Since then, the management has been wary of investing in training.

Quantitatively, training significantly predicts CHC. Indeed, $\mathrm{R}^{2}$, which estimates the contribution of each variable to the proposed model, shows a significant contribution $\left(\mathrm{R}^{2=} 0.21, p<.00\right)$ of training to CHC. In other words, training explains $21 \%$ of the variation in the $\mathrm{CHC}$ construct in the companies studied. As for the standardized coefficient $(b=0.19)$, it means that with each improvement in the scale of continuous training quality, the level of $\mathrm{CHC}$ of the predicted organization increases. Similarly, the standardized 
coefficient beta $(\beta=0.23)$, which expresses the regression coefficient of the training variable, shows that this variable contributes to the prediction of $\mathrm{CHC}$ and this when considering a one standard deviation increase in the variables. The value of the T-test $(t=8.62 ; p<.00)$ indicates that the contribution of training to explaining the organization's $\mathrm{CHC}$ level is statistically significant. These results support Hypothesis 1 regarding the prediction of organizational $\mathrm{CHC}$ by training investments.

\section{Hypothesis 2. Staff Management Practices Improve Human Capital Competence.}

Qualitatively, it appears from the HR managers' opinions that:

...] Here, employee support practices are an integral part of our corporate culture and begin at the induction phase to promote integration. We know and are aware that the suitability of a new employee depends on the quality of the support we provide. For example, the accounting department has set up a system for this purpose, as does the sales department, which offers group coaching and workshops to all sales agents.

We have an entire budget line dedicated to the supervision and support of new employees, which begins at the induction stage and continues through to integration. This makes our sales agents, for example, very autonomous two weeks after they start work. As a result, we have had consistently positive results from our agents. Thus, our employees are always able to perform their tasks in a structured way and thus helped to achieve our vision of leadership.

These opinions attest to the importance of coaching as a relevant tool in building workplace $\mathrm{CHC}$ in the reception stage.

Quantitatively, coaching practices also predict CHC. Indeed, according to the data in Table 8, the $\mathrm{R}^{2}$ coefficient shows a significant contribution $\left(\mathrm{R}^{2=} 0.48, p<.00\right)$ of management on CHC. In other words, management explains an additional $27 \%$ of the variation in the $\mathrm{CHC}$ construct in the firms studied. The coefficient $(\mathrm{b}=.28)$ means that with each improvement in the scale of managerial quality, the level of CHC increases. The same is true for the beta coefficient $(\beta=0.23)$. The value of the T-test $(t=8.72)$ indicates that this contribution to explaining the level of $\mathrm{CHC}$ is significant. Such results support hypothesis 2.

Hypothesis 3. The More Experience Opportunities the Organization Creates, the More Competitive Its Human Capital Would Be.

The interview results show that the factors of experience opportunity and seniority increase the suitability of staff for the tenure stage.

[...] thanks to our business networks, we have been able to diversify the experience capital of our staff during the last two years on both the technical and administrative aspects. For example, in November 2019, two of our occupational health and safety staff went on a three-day impregnation trip to our partner in charge of occupational health and safety. Following this visit, information and awareness workshops were held for all other employees. As a result, today, the rate of work-related accidents has been considerably reduced, I would say by $80 \%$.

Some HR managers, in emphasizing experience as a strategy for empowering staff, emphasized the contribution of technical partners.

...] the technical support agreement with a social auditing consultancy has enabled our company to master and apply the principles of Corporate Social Responsibility. And, in two to three years, we could be certified. 
These opinions demonstrate the importance of building $\mathrm{CHC}$ through experiential opportunities during their tenure stage.

Quantitatively, experience opportunities significantly predict $\mathrm{CHC}$. The $\mathrm{R}^{2}$ coefficient shows a significant contribution $\left(\mathrm{R}^{2=} 0.64, p<.00\right)$ of experience on CHC. In other words, coaching explains an additional $16 \%$ of the variation in the $\mathrm{CHC}$ construct across the firms studied. The coefficient $(\mathrm{b}=.31)$ means that with each improvement in the scale of coaching quality, the level of CHC increases. The same is true for the beta coefficient $(\beta=0.34)$, which shows this same contribution. The value of the T-test $(t=$ 8.77) indicates that this contribution to explaining the level of $\mathrm{CHC}$ is significant. Such results support hypothesis 3.

Hypothesis 4. The Agile Environment Contributes to the Construction of CHC.

Qualitatively, proponents of organizational HRM believe that collective learning, self-organization and teamwork are factors in building competitive human capital.

[...] to make our collaborators agile, we promote teamwork, which is part of one of our values, because we know that this way of working promotes collective learning, experience sharing and conflict resolution. Through team training and operationalization, our collaborators have been increasing our performance in organizational and social innovation since 2018.

In the same vein, other leaders recognize that the agile environment supports the acceleration of staff innovation skills during the tenure stage.

I am not an innovation specialist, but according to the testimonies of some of my employees, it seems that giving them more autonomy in certain aspects of management fosters creativity, but also ensures their ongoing commitment to their jobs and missions. And our social partners support us in this approach...

Finally, according to Table 8 , agility also predicts CHC. The $\mathrm{R}^{2}$ coefficient $\left(\mathrm{R}^{2=} 0.83, p<.00\right)$ shows a significant contribution of agility on CHC. This means that agility explains $19 \%$ of additional variance in the $\mathrm{CHC}$ construct in the companies studied. The regression coefficient $(b=0.29)$ means that with each improvement in the quality of agility, the level of CHC increases. Similarly, the beta coefficient $(\beta=0.33)$ shows that agility contributes to the prediction of CHC. The T-test value $(t=8.92)$ indicates that this contribution to the explanation of CHC level is significant. Such results support hypothesis 4 .

Ultimately, although each variable significantly predicted the CHC construct, it was the combination of the four factors that played a decisive role $\left(\mathrm{R}^{2=} 0.83\right)$ in predicting $\mathrm{CHC}$. Consequently, all four hypotheses are supported by the results.

TABLE 8

PREDICTORS OF COMPETITIVE HUMAN CAPITAL IN THE WORKPLACE

\begin{tabular}{l|l|l|l|l|l}
\hline Variables & $\mathbf{R}^{\mathbf{2}}$ & $\boldsymbol{b}$ & $\beta$ & $\boldsymbol{t}$ & $\boldsymbol{p}$ \\
\hline Constant & & 2,17 & 2,37 & 8,62 &, 00 \\
\hline Training & 0,21 & 0,19 & 0,23 & 8,72 &, 00 \\
\hline Framing & 0,48 & 0,28 & 0,32 & 8,77 &, 00 \\
\hline Experience & 0,64 & 0,31 & 0,34 & 8,82 &, 00 \\
\hline Agility & 0,83 & 0,29 & 0,33 & 8,92 &, 00 \\
\hline
\end{tabular}




\section{Discussion}

The purpose of the study was to identify variables to be used to construct and test a model of competitive human capital in an organizational setting during the onboarding, integration, and tenure stage by variables deemed relevant from a theoretical and practical perspective.

Overall, the results of this study indicate that the business practices studied, through investments in training, coaching, experience, and the agile environment, generate competitive human capital in organizational settings from the onboarding stage through tenure. These results are significantly consistent with previous work (Becker, 2009; Nafukho et al., 2004; Poulain, 2001; Robinson et al. , 2008; Schultz, 1961) .

Specifically, according to the qualitative and quantitative results, training is positively and statistically significantly associated with competitive human capital (hypothesis 1) from the integration stage. Similarly, it improves and contributes significantly to the prediction of CHC. Such results are not accidental. Indeed, training, according to the words of several theorists and practitioners, is a stimulant that allows to respond to daily reactions and problems in organizational settings (Lleras, 2004; OECD, 1998; Yaroson et al., 2017). These results can also be explained by the fact that training is a means by which the employee can have the best self-esteem, but also recognize their strengths and talents for the organization during their stay. For the employee, it increases the sense of belonging to the organization; it also breaks down the silos in the organization. For the organization, continuous training allows it to retain the best candidates. It is one of the key elements of the corporate culture that guarantees its competitive position (Mengistae, 2006). Therefore, regular investment in continuous training is a strategy to achieve CHC within the organization. These results are similar to those obtained by several previous studies (Becker, 1962; Lleras, 2004; OECD, 1998). Indeed, according to the results of these authors, training investments positively and significantly predict competitive human capital. However, some of our qualitative empirical results are not very consistent with the literature.

Secondly, management practices have a positive influence on CHC (hypothesis 2) from the induction and integration stage. This result is not surprising given that management plays an extremely important role in supporting and communicating with employees, but also in organizing capitalization. This is how the supervision of new recruits effectively contributes to the construction of their capital (Santos, 2012; Yaroson et al., 2017).

Similarly, experience opportunities also participate in the construction of $\mathrm{CHC}$ in the organization during the tenure stage. The relationship that emerges is positive and statistically significant as suggested by hypothesis 3 . These work experiences are often associated with competitive human capital according to several works on human resource management (Antonelli et al., 2010; Baranwal, 2018; Robinson et al., 2008). The fact that such findings emerge for the firms studied in Chad extends those from other contexts (Châteauneuf-Malclès, 2016; Chung, Park, Lee, \& Kim, 2015; Hayton, 2003).

Finally, organizational agility promotes $\mathrm{CHC}$ building from integration to tenure. Such a result is not surprising considering that agility plays an extremely important role in making staff more "intelligent", efficient and autonomous. Furthermore, agility, introduced as a $\mathrm{CHC}$ construct variable, is a strategic and organizational response to environmental fluctuations. Our results corroborate those in the literature that report that agility rhymes with mobility and responsiveness (Legras, 2014; LeMay, 2019; Moinet, 2007). Agile companies are able to respond quickly but effectively to environmental constraints. These results can also be explained by the fact that agility conveys values and principles that allow work teams to develop a shared language, but also to develop a collective intelligence and a collaborative work mode (Legras, 2014; Moinet, 2007).

In light of the above, we can emphasize that the impact of training, coaching, experience and agility on human capital, from the induction stage to that of permanence, is independent of the economic situation of the country and the sectors of the companies studied. Rather, it depends on the management styles of the company, which are favorable to the enrichment and development of the person considered as a subject of growth and not as a production resource. The second explanation associated with these results is that human capital is a cognitive concept inserted in a theoretical corpus, but also the result of practices on the ground of daily maneuvering of the company's activities. As our results show so well, the suggested model is a 
model of human action constructed in such a way that an initiative (training, coaching, etc.), for the benefit of the person within the organization, is understandable both for the actor himself and for the beneficiary and his fellow human beings (Becker, 1962, 2009; Lleras, 2004). This action is part of the current interpretation of the person's daily life as a subject of corporate growth (Schultz, 1961).

Based on the discussions that emerge with convergent, divergent and complementary points of view, we can consider theoretical, methodological and managerial implications, highlight limitations and suggest avenues. This is the purpose of the following lines.

\section{CONTRIBUTION OF THE PRESENT STUDY}

\section{Theoretical Contribution}

Our article aims to contribute to the advancement of studies on the development of human capital in the workplace from the induction stage. The factors put forward by previous scientific works are, for the most part, related to management practices. While the relationships tested between management practices, notably training and competitive human capital, are direct relationships. The results of the said previous works have led to the conclusion that continuous qualifying training and experience effectively participate in the construction of competitive human capital in the workplace. But variables such as leadership and agility were not explicitly included in the models. Also, the explicit formal definition of human capital (HC) has not been proposed. Thus, the main theoretical contribution of this study is to have introduced, in the theoretical model, coaching and agility as variables of competitive human capital construction in the workplace. It is especially the combination of these four variables that constitutes the major theoretical contribution. Similarly, we have proposed a definition of HC that still needs improvement.

We have shown that in the process of building human capital in the workplace, the agile environment and coaching have a strong explanatory power for better human capital. In other words, the promotion of collaborative management, worker empowerment, staff coaching, and support initiatives play a key role in the production pathway of skilled staff. Conversely, a mechanical management style inhibits the development of human capital. This research shows that it is not only training that can produce competitive human capital.

In addition to the above contributions, this study brings out new theoretical avenues. Indeed, the identification and testing of new variables, notably "agile environment" and "coaching" constitute the contribution to the valuation of human capital innovation in the workplace. This approach, of which the suggested model is the manifestation, had not been the subject of a study that deployed a rigorously empirical qualitative and quantitative specification. It thus emerges that human capital in an organizational environment, in order to be competitive, requires specific investment in collaborative/cooperative management practices. Consequently, the following two main theoretical avenues are in the crosshairs: (i) cooperative management theory; and (ii) participatory management theory. Proponents (Jacquet, 2013; March and Olsen, 1984; Ouchi and Chung, 1982) of these schools of thought emphasize training, wellbeing at work and the importance of the organization as an open system with a social vision to achieve greater competitiveness.

\section{Methodological Contribution}

In general, the adoption of the simultaneous mixed method (qualitative and quantitative) is the major methodological contribution. Specifically, the adoption of the new constructs and the adaptation of the contents of the items forming the dimensions of the variables used in the context of this article represent a remarkable methodological contribution, as the previous studies did not take into account the constituents specific to the object of the research. In fact, the hypothetico-deductive study carried out has made it possible to highlight items specific to our study context.

Then, after correlational and explanatory analysis, several items were found to be reliable and relevant. These included: (i) organizational flexibility; (ii) support for new recruits; (iii) risk tolerance; (iv) training policy; and (v) organizational autonomy. These are the items that were formulated by us in the course of 
this work. Thus, the reliability and relevance of these items are among the remarkable methodological contributions.

Finally, the mixed design deployed constitutes an undeniable methodological contribution. In fact, this strategy has made it possible to minimize the limitations of the qualitative and quantitative approaches. It is a strategy that allowed for a more detailed and complete understanding of the problem of building competitive human capital at work. This approach was deployed in a phase in which qualitative and quantitative data were generated simultaneously and iteratively. In addition, the side-by-side analysis of the combination of qualitative and quantitative approaches allowed for the documentation of understudied concepts/variables, notably "agility" and "experience".

\section{Managerial Contributions}

The identification of the variables coaching and agility, which play a significant role in the construction of competitive human capital in the workplace, represents a concrete contribution for all actors involved in the process of human capital development. Indeed, the highlighting of positive and statistically significant relationships between continuous training, experience, coaching, agility and competitive human capital is an important element on which personnel managers, consultants and HRM researchers can rely to suggest and enrich human capital management practices.

Similarly, this study has highlighted the explanatory power of the agile environment, coaching and training on competitive human capital. For training, on the other hand, the results showed that some organizations are not very supportive. However, given the brutal and accelerated nature of the current socioeconomic ecosystem, this study recommends that HR managers put more emphasis on training related to the use of social networks, IT tools, but also coaching and agile methods in their human capital management practice. Specifically, it is desirable that emphasis be placed on the various dimensions of agility and therefore collective intelligence to promote the development of human capital.

In any case, this work has shown that the combination of training, experience, coaching and agility plays a more significant role in building competitive human capital than differentiated employment. This result is fundamental for business leaders who have to deal with the competitive, brutal and ever-changing environment.

\section{LIMITATIONS AND FUTURE DIRECTIONS}

In addition to the contributions, this study also has limitations. First, the results of our study are based on information provided by a sample of 178 HRM stakeholders in the context of the new economy. Compared to several other studies conducted on human capital, our research led to the same result, namely that the relationship between management practices (training, coaching, experience, and agility) and CHC is positive and statistically significant. But this result should, however, be viewed with caution when generalized to other contexts. In our opinion, the result depends much more on the internal context of the company and the sample selected. It therefore seems useful to study more than three samples of companies at the same time: samples characterized by developed social policies and samples where company practices are not very visible. The second limitation is that the $\mathrm{CHC}$ construction axis was studied in its static aspect, insofar as the respondents, mostly department heads, were asked to provide their assessment of the initiatives developed by their company. Thus, a longitudinal approach, integrating personnel from several hierarchical levels, is necessary in future research. In addition, several interesting topics are left open for future research. This study leaves us convinced that investments in training, coaching practices, agile environment, etc. increase the construction of $\mathrm{CHC}$ under certain conditions from the onboarding phase; this was demonstrated by our research. Future research should pay more attention to this issue while introducing other variables, such as innovation in its different dimensions and moderating/mediating variables, as our study tested the direct relationship between $\mathrm{CHC}$ and training, coaching, agility, etc. 


\section{CONCLUSION}

Our initial research question, "What variables are considered relevant to developing the best model of $\mathrm{HC}$ in an organization? At the outset, the exploration of the literature made it possible to explicitly trace the trajectory of four relevant variables that allowed us to suggest the model for the construction of HC in the workplace. Then, our empirical results showed that, in addition to training and experience, coaching/coaching and the agile environment significantly demonstrated their explanatory power on the process of building competitive human capital (induction, integration and tenure stages) in the workplace. It is the introduction of the variables coaching/support and agile environment that have shed light on the construction of human capital. However, it is primarily the combination of these four factors that plays a key role in fertilizing the skill of the workforce in the workplace. However, it should be noted that the study is conducted without considering contingent factors, including the ecosystem and moderating/mediating variables.

In any case, the results of our study lead us to believe that placing the issue of human capital development at the center of the company's mission today is a question of responsibility and not of freedom. Thus, the proposed model is an object of thought that would contribute to enriching the actions of HR, but also to determining the behavior of the H.C. manager, to defining the goal of his actions and to prescribing the means to achieve them (Schultz, 1961). Moreover, it is, to use Schultz's words (1987), a second-degree construction, because human capital is both a cognitive concept, inserted in a theoretical corpus and a category of practice.

Moreover, building human capital in the workplace is not only a responsibility, but also a duty, in the sense that no organization should be afraid to engage in it, regardless of its size and resources. If it consciously invests in training, experience opportunities, coaching initiatives and improving management style, it can achieve better performance and be among the most competitive companies in a competitive environment.

In short, it is important to go much further in the investigations on the construction of competitive human capital in the organizational environment and on the most relevant management practices for its valorization. The present research needs a better understanding of the practices of human capital valorization in the current world characterized by the innovation economy and not by catching up. In any case, the major expectations are related to training policies, to the modes of supervision/accompaniment, and to the creation and enrichment of an agile environment to promote the valorization of human capital. This study reveals a field that still has strong research potential, but whose expectations in terms of conceptualization are still not being met.

\section{ACKNOWLEDGEMENT}

Translated \& edited by American Publishing Services (https://americanpublishingservices.com/).

\section{REFERENCES}

Ahmad, S.B., \& Mushraf, A.M. (2011). The Relationship between Intellectual capital and Business Performance: An empirical study in Iraqi industry. International Conference on Management and Artificial Intelligence, pp. 1-6.

Al-Duajaili, M.A.A. (2012). Influence of Intellectual Capital in the Organizational Innovation. International Journal of Innovation, Management and Technology, 3(2), 128-135.

Anie-Tchad. (2017). Guide d'Installation des Entreprises au Tchad (p.47).

Antonelli, G., Antonietti, R., \& Guidetti, G. (2010). Organizational change, skill formation, human capital mesurement: Evidence from Italian manufacturing firm. Journal of Economic Surveys, 24(2), 206-247. 
Baranwal, G. (2018). Links between foreign direct investment and human capital formation: Evidence from the manufacturing sector in India. The Journal of International Trade \& Economic Development, pp. 1-24. doi:10.1080/09638199.2018.1508304

Barney, J.B. (1991). Firm Resources and Sustained Competitive Advantage. Journal of Management, 17, 99-120.

Becker, G.S. (1962). Investment in Human Capital: A Theoretical Analysis. Journal of Political Economy, 70(5), 9-49.

Becker, G.S. (2009). Human capital: A theoretical and empirical analysis, with special reference to education. University of Chicago Press.

Bessieux-Ollier, C., \& Walliser, É. (2010). Le capital immatériel État des lieux et perspectives. Revue Française De Gestion, (207), 85-92.

Bosma, N., Praag, M.V., Thurik, R., \& Wit, G.D. (2002). The Value of Human and Social Capital Investments for the Business Performance of Startups. EIM Business and Policy Research, pp. 120.

Bouteiller, D., Cossette, M., Fournier, C., \& Sabourin, N. (2013). Capital humain et performance(s). Cadres théoriques et protocoles de mesure. HEC Montréal, p.241.

Chamak, A., \& Fromage, C. (2006). Le capital humain. Editions Liaisons.

Châteauneuf-Malclès, A. (2016). LE CAPITAL HUMAIN, une source de compétitivité délaissée ? Idées Economiques et Sociales, 2(184), 25-34.

Chung, C.C., Park, H.Y., Lee, J.Y., \& Kim, K. (2015). Human capital in multinational enterprises: Does strategic alignment matter? Journal of International Business Studies, 46, 806-829.

Creswell, J. (2013). Research Design: Qualitative, Quantitative, and Mixed Method Approaches (4 $\left.{ }^{\text {th }}\right)$. Sage, 4, 1-285.

Crook, T.R., Combs, J., Todd, S., Woehr, D., \& Ketchen, J. (2011). Does human capital matter? A metaanalysis of the relationship between human capital and firm performance. Journal Application Psychologic, 96(3), 443-456.

Evrard, Y., Pras, B., Roux, E., Desmet, P., Dussaix, A-M., \& Lilien, G. (2009). Market - Fondements et méthodes de recherches en marketing.

Fraisse-D’Olimpio, S. (2009). Les fondements théoriques du concept de capital humain (Partie 1). OCDE.

Hayton, J.C. (2003). Strategic human capital management in SMEs: An empirical study of entrepreneurial performance. Human Resource Management, 42(4), 375-391.

Jacquet, S. (2013). Du management participatif...au management coopératif : Coopérer pour construire et donner du sens au management. Creg.ac.versailles, pp. 1-17.

Kalkan, A., Bozkurtb, Ö.Ç., \& Arman, M. (2014). The impacts of intellectual capital, innovation and organizational strategy on firm performance. Procedia - Social and Behavioral Sciences, 150(2014), 700-707.

Keeley, B. (2004). Le capital humain: Comment le savoir déterminer? Les essentiels de l'OCDE, 163.

Kungwansupaphan, C., \& Siengthai, S. (2012). Exploring entrepreneurs' human capital components and effects on leaming orientation in early internationalizing firms. International Entrepreneurship and Management Journal, pp. 1-27.

Legras, S. (2014). L'agilité, nouvelle transformation pour l'entreprise. Documentaliste-Sciences de l'Information, 51(4), 4-6.

LeMay, M. (2019). Agile for Everybody. O’Reilly Media, p.135.

Lev, B., \& Han, D. (2015). The Relationship between Intellectual Capital and Corporate Performance in Chinese Bio-pharmaceutical Industry. SHS Web of Conferences., 0102, 1-7.

Lleras, M.P. (2004). Investing in Human Capital: A Capital Markets Approach to Student Funding (p.248). Cambridge University Press, New York.

March, J., \& Olsen, J. (1984). The New Institutionalism: Organizational Factors in Political Life. The American Political Science Review, 78(3), 734-749.

Mengistae, T. (2006). Competition and entrepreneurs' human capital in small business longevity and growth Taye Mengistae. The Journal of Development Studies, 42(5), 812-836. 
Moinet, N. (2007). L'agilité stratégique: Une question de dispositif intelligent. Vie \& Sciences de l'entreprise, (174-175), 142-155.

Nafukho, F.M., Hairston, N., \& Brooks, K. (2004). Human capital theory: Implications for human resource development. Human Resource Development International, 7(4), 545-551.

OCDE. (1998). L'investissement dans le capital humain : Une comparaison internationale. OCDE, p.121.

OCDE. (2013). Nouvelle source de croissance: Le capital intellectuel, analyses de base et conclusion pour l'action gouvernementale. $O C D E$, p.73.

Ouchi, W., \& Chung, K. (1982). Theory Z: How American Business Can Meet the Japanese Challenge. The Academy of Management Review, 7(2), 317-319.

Oxley, L., Lee, T., \& Gibson, J. (2008). Measuring human capital: Alternative methods and international evidence. The Korean Economic Review, 24(2), 63.

Poulain, É. (2001). Le capital humain, d'une conception subtantielle à un modèle représentationnel. Revue Economique, 52(1), 91-116.

Robinson, D., Hooker, H., \& Mercer, M. (2008). Human Capital Measurement: Approaches, issues and case studies. Workforce Planning Guide, p.86.

Rodriguez, J.P., \& Loomis, S.R. (2007). A new view of institutions, human capital, and market standardisation. Education, Knowledge and Economy, 1(1), 93-105. doi:10.1080/17496890601128357

Santos, M.E. (2012). Human Capital and the Quality of Education in a Poverty Trap Model. Oxford Development Studies, 39(1), 25-47.

Schultz, T. (1961). Investment in Human Capital. The American Economic Review, 51(1), 1-17.

Stiglitz, J.E., Greenwald, B.C., Aghion, P., Arrow, K.J., Solow, R.M., \& Woodford, M. (2014). Creating a Learning Society: A New Approach to Growth, Development, and Social Progress. Columbia University Press.

Ugalde-BindaI, N., Balbastre-Benavent, F., Canet-Giner, T., \& Escribá-Carda, N. (2013). The role of intellectual capital and entrepreneurial characteristics as innovation drivers. Innovar, 24(53), $41-$ 60.

Unger, J., Rauch, A., Frese, M., \& Rosenbusch, N. (2011). Human capital and entrepreneurial success: A meta-analytical review. Journal of Business Venturing, 26, 341-358.

Vinokur, A. (2014). Pourquoi le “capital” humain? L'Harmattan, pp. 1-11.

Yaroson, E.V., Esew, N.G., \& Abdul-Qadir, A.B. (2017). Human capital development in Nigeria: An empirical assessment on the impact of corruption. African J. Economic and Sustainable Development, 6(1), 86-103. 